\title{
The Impact of Disease Activity in Patients with Rheumatoid Arthritis on Metabolic Syndrome and Cardiovascular Risk Assessment
}

\author{
Ivana Aleksić ${ }^{1}$, Sonja Stojanović1,2, Ivan Tasić ${ }^{1,2}$, Bojana Stamenković1,2 \\ ${ }^{1}$ Institute for Treatment and Rehabilitation "Niška Banja", Niš, Serbia \\ ${ }^{2} U$ niversity of Niš, Faculty of Medicine, Nišs, Serbia
}

\author{
SUMMARY
}

Patients with rheumatoid arthritis (RA) have a 1.5 times higher cardiovascular disease mortality compared to the general population, while the life expectancy of these patients is 5-10 years shorter compared to the general population. In RA patients, all stages of atherogenic process are accelerated. Systemic inflammation underlying RA is an independent risk factor for the development of cardiovascular diseases.

The main objectives of the study were: a) to examine the lipid status and frequency of metabolic syndrome in RA patients and their association with disease activity and functional impairment; $b$ ) to assess the cardiovascular risk of RA patients in relation to disease activity and presence of metabolic syndrome components.

Investigation was performed in RA patients diagnosed according to classification criteria the American Association of Rheumatologists (1987). All RA patients underwent clinical examination, laboratory analyses, measurement of blood pressure, body weight and height (body mass index was calculated). The presence of the metabolic syndrome (MetS) was determined by the definition of the International Federation for Diabetes. ACC/AHA ASCVD risk calculator was used to calculate the cardiovascular risk. Disease activity was evaluated with DAS28 and CDAI score. Functional ability of patients was assessed based on the modified Health Assessment Questionnaire (HAQ). Comparison of continuous variables was performed by the Mann-Whitney test, while comparison of the attributes was performed with the Chi-square test. Statistical data processing was performed in the program package $R$.

The study enrolled 81 RA patients (19 men and 62 women) whose mean age was $59.7 \pm 11.2$ years, with average disease duration of $5.89 \pm 6.25$ years. According to disease activity measured by DAS28, all patients were divided into two groups - high disease activity group (HAD) with DAS28 $>5.1$ which consisted of 37 patients (45.7\%) and moderate, low disease activity and remission (MLA) group with DAS28 $\leq 5.1$, which consisted of 44 patients $(54.3 \%)$. The average total cholesterol level in all patients was $5.44 \pm 1.03$. Total cholesterol was $5.22 \pm 1.03$ in HAD group and $5.68 \pm 1.03$ in MLA group $(p=0.029)$. The average level of LDL cholesterol in all patients was $3.09 \pm 0.80$. In the HAD group, the levels were statistically significantly lower $(p=0.033)$ compared to the MLA 
group ( $2.84 \pm 0.80$ vs. $3.34 \pm 0.80)$. The prevalence of metabolic syndrome in the study population was $54.3 \%(44 / 81$ patients). Patients with metabolic syndrome had statistically significantly higher DAS28 values

$(p=0.004)$, CDAI $(p=0.007)$ and higher functional incapacity determined by HAQ questionnaire $(p=0.001)$. Cardiovascular risk in the HAD group was $12.18 \pm 8.09 \%$ which was higher compared to MLA group $10.74 \%$, but without significance between the compared groups $(p=0.943)$. Cardiovascular risk was statistically significantly higher in patients with metabolic syndrome $(\mathrm{p}<0.001)$.

Our results suggest statistically significantly more frequent presence of metabolic syndrome in RA patients, which is accompanied with higher disease activity and more severe functional disability.

Total cholesterol and LDL cholesterol levels were lower in patients with high disease activity.

Cardiovascular risk was statistically significantly higher in patients with metabolic syndrome and RA, but without a significant difference regarding the disease activity.

Key words: rheumatoid arthritis, lipid profile, metabolic syndrome, cardiovascular risk

Corresponding author:

Ivana Aleksić

E-mail: i.aleksic@hotmail.com 


\section{INTRODUCTION}

Rheumatoid arthritis (RA) is an autoimmune, chronic systemic inflammatory disease, characterized by symmetric polyarthritis that prograde over time and leads to severe joint impairment and disability (1). A tenyear follow-up of RA patients showed 2-3 times higher relative risk of cardiovascular disease (CVD) compared to the healthy individuals of the same sex and lifespan. Some data suggest that RA patients have 1.5 times higher mortality from CVD compared to the general population, and that life expectancy of these patients is 5-10 years shorter compared to the general population (2). Out of all CVD's, the most common cause of mortality is ischemic heart disease observed in about $50 \%$ of cases. The most common cause of ischemic heart disease in patients with RA (90\% of patients) is atherosclerosis of coronary arteries. The impairment to endothelium is under the influence of various factors leading to the formation of atherosclerotic plaque, with a particularly significant role of attached inflammatory cells (macrophages, lymphocytes, monocytes, NK cells) and various inflammation mediators ( $C$ reactive protein, fibrinogen, interleukin-I, interleukin-6, tumor necrosis factor alpha TNF- $\alpha$ ). Factors that affect endothelial impairment lead to the activation and proliferation of inflammatory cells, smooth muscle cells, cytokine production, growth factor, and other mediators that promote the progression of atherosclerosis (3).

The bad outcome of CVD in RA patients is associated with the markers of the worse RA outcome such as seropositivity, degree of systemic inflammation, the number of painful and swollen joints, and the presence of extraarticular manifestations. In patients with RA, all stages of atherogenic process are accelerated. Systemic inflammation underlying RA is an independent risk factor for the development of cardiovascular diseases (4).

Since peripheral arthritis is the main clinical manifestation of the disease, the number of swollen and painful joints is the main parameter of the disease activity and severity. Due to its simplicity, the most widely used outcome measure for RA is a modified disease activity score 28 (mDAS28), assessing the pain and swelling in 28 joints in joint areas typical for rheumatoid arthritis (5). Considering other clinical parameters, the functional ability of patients is evaluated using the modified Health Assessment Questionnaire (mHAQ) (6). Pain and general health are assessed using the visual analogue scale (VAS), performed by patients and physicians.

Standard laboratory tests include the estimatation of sedimentation rate (ESR), concentration of C-reactive protein $(\mathrm{CRP})$, rheumatoid factor $(\mathrm{RF})$ and anti-citrullinated antibodies (anti-CCP), and more recently the concentration of proinflammatory cytokines. While ESR and CRP are the parameters for assessing disease activity, rheumatoid factor and anti-CCP antibodies have prognostic significance $(7,8)$.

\section{A IM}

The aim of the study was first to examine the lipid status and frequency of metabolic syndrome in RA patients and their association with disease activity and functional impairment, and secondly, to assess the cardiovascular risk in RA patients in correlation with disease activity and individual components of metabolic syndrome.

\section{MATERIAL AND METHODS}

The study included 81 RA patients (19 men and 62 women), diagnosed by the American Association of Rheumatologists in 1987 classification criteria. The mean age was $59.7 \pm 11.2$ years, and the average disease duration was $5.89 \pm 6.25$ years.

All patients were treated with a disease modifying drug methotrexate (MTX) in the dose of $10-20 \mathrm{mg}$ per week, while the dose of prednisolone was 5-10 mg per day. An average doze of MTX was $15 \mathrm{mg}$ per week and average dose of prednisolone was $7.5 \mathrm{mg}$ per day. Three patients received a combined therapy with methotrexate and sulfasalazine (MTX+SSZ), while none of the patients received a biological drug therapy. The average duration of MTX therapy was $4.65 \pm 3.25$ years and $3.26 \pm 2.85$ years of a combined therapy. There were no changes in therapy in the last year.

In all RA patients we performed: a) clinical rheumatological examination (the number of tender and swollen joints); b) blood sampling for laboratory analyses (estimatation of sedimentation rate (ESR), concentration of C-reactive protein (CRP), rheumatoid factor (RF), blood glucose levels (gly), cholesterol (Hol), LDL cholesterol (LDL), HDL cholesterol (HDL), triglycerides (Tg)); c) blood pressure measurement; d) body weight and height evaluation and calculation of body mass index (BMI). Blood pressure was measured in a seated position after 10 minutes of rest.

The presence of the metabolic syndrome was determined by the definition of the International Federation for Diabetes. The definition describes the metabolic syndrome as the existence of at least three risk factors, such as body mass index (BMI>25), increased blood 
triglyceride concentration $(\mathrm{Tg}>1.7)$, decreased good cholesterol (HDL $<1.02$ for men and $<1.29$ for women) in blood, increased blood pressure (systolic $>130$, diastolic $\geq 85 \mathrm{mmHg}$ ) and increased blood glucose level (gly $>6.1 \mathrm{mmol} / \mathrm{l})(9)$.
ACC/AHA ASCVD risk calculator was used to calculate the cardiovascular risk (Figure 1) (10).

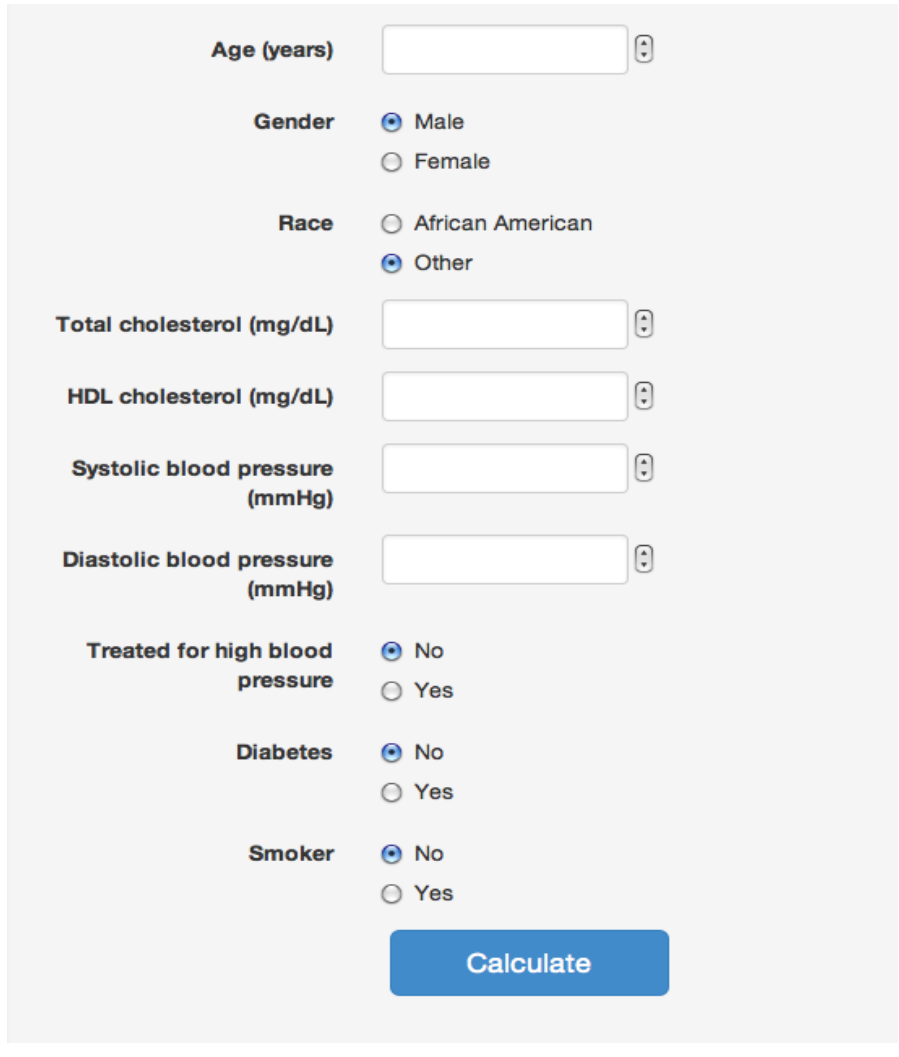

Figure 1. The cardiovascular risk calculator (link: http://www.cvriskcalculator.com/)

Modified disease activity score 28 (mDAS28) and the clinical disease activity index (CDAI) were calculated based on the above parameters. The number of tender and swollen joints was performed in 28 joints and joint regions typical for rheumatoid arthritis (shoulders, elbows, wrists, metacarpophalangeal, proximal interphalangeal joints of hands and knees) and used to calculate the Disease Activity Score - DAS28 (11). Disease activity was additionally evaluated using visual analogue scale with values ranging from 0 to $100 \mathrm{~mm}$. A larger number on the VAS scale indicates a higher level of disease activity (12).

Functional ability of RA patients was assessed by the modified Health Assessment Questionnaire (mHAQ) consisting of 8 domains. The assessment of disease se- verity is obtained using targeted questions each scored with 0-3. The maximum value of the HAQ score is 3 (13).

Statistical analysis for the numeric variables are presented as arithmetic mean \pm standard deviation. Comparison of continuous variables was performed by the Mann-Whitney test, and the comparison of the attributes was performed with the Chi-square test. The hypothesis was tested with a significance threshold $p<0.05$. Statistical data processing was performed in the program package $R$.

\section{RESULTS}

The research was conducted at the Institute for Treatment and Rehabilitation "Niška Banja" in 2018, and it was designed as a cross-sectional study. 
According to disease activity measured by DAS28, all patients were divided into two groups: high disease activity (HAD) group with DAS28 > 5.1 which consisted of 37 patients (45.7\%) and moderate, low disease activity and remission (MLA) group with DAS28 $\leq 5.1$ which consisted of 44 patients (54.3\%). In the MLA group, moderate activity (DAS28 $\geq 3.2-\leq 5.1$ ) was reported in $36(44.4 \%)$ patients, low activity (DAS28 $\geq 2.6-<3.2$ ) in 6 $(7.4 \%)$, and remission (DAS28 < 2.6) in $2(2.5 \%)$ patients.

According to disease activity measured by CDAI score, high disease activity (CDAI: 22.1-76.0) was reported in 34 patients (42\%), moderate (CDAI: 10.1-22.0) in 39 (48.1\%) patients, low disease activity (CDAI: 2.9-10.0) in
$6(7.4 \%)$, while the remission of disease (CDAI: 0.0-2.8) was observed in 2 patients (2.5\%).

The average total cholesterol level in all patients was $5.44 \pm 1.03$. Total cholesterol was $5.22 \pm 1.03$ in HAD group and $5.68 \pm 1.03$ in MLA group $(p=0.029)$. The average level of LDL cholesterol in all patients was $3.09 \pm$ 0.80 . In the HAD group the levels were statistically significant lower $(\mathrm{p}=0.033)$ compared to the MLA group $(2.84 \pm 0.80$ vs. $3.34 \pm 0.80)$.

Metabolic syndrome was found in 24/37 patients (64.86\%) in HAD group and 20/44 (45.45\%) patients in MLA group $(\mathrm{p}=0.042)$ (Table 1$)$.

Table 1. Lipid status and parameters of metabolic syndrome by disease activity in RA patients

\begin{tabular}{l|c|c|c}
\hline \hline & $\begin{array}{c}\text { DAS28 }>1 \\
\text { HAD }\end{array}$ & $\begin{array}{c}\text { DAS28 } \leq 5.1 \\
\text { MLA }\end{array}$ & $p$ \\
\hline Total cholesterol & $5.22 \pm 1.03$ & $5.68 \pm 1.03$ & 0.029 \\
\hline LDL cholesterol & $2.84 \pm 0.80$ & $3.34 \pm 0.80$ & 0.033 \\
\hline HDL $<1.02 / 1.29$ & $26(70 \%)$ & $22(50 \%)$ & 0.105 \\
HDL $\geq 1.02 / 1.29$ & $11(30 \%)$ & $22(50 \%)$ & 0.789 \\
\hline Tg $>1.7$ & $18(48.64 \%)$ & $19(43.18 \%)$ & 0.733 \\
Tg $\leq 1.7$ & $19(51.36 \%)$ & $25(56.82 \%)$ & 0.243 \\
\hline gly $>6.1$ & $4(10.8 \%)$ & $7(15.9 \%)$ & \\
gly $\leq 6.1$ & $33(89.2 \%)$ & $37(84.1 \%)$ & 1.000 \\
\hline BMI $>25$ & $25(67.6 \%)$ & $23(52.3 \%)$ & \\
BMI $\leq 25$ & $12(32.4 \%)$ & $21(47.7 \%)$ & 1.000 \\
\hline Systolic TA $>130$ & $1(2.7 \%)$ & $1(2.3 \%)$ & \\
Systolic TA $\leq 130$ & $36(97.3 \%)$ & $43(97.7 \%)$ & 0.042 \\
\hline Diastolic TA $\geq 85$ & $1(2.7 \%)$ & $1(2.3 \%)$ & \\
Diastolic TA $<85$ & $36(97.3 \%)$ & $43(97.7 \%)$ & \\
\hline With MetSy & $24(64.86 \%)$ & $20(45.45 \%)$ & \\
Without MetSy & $13(35.14 \%)$ & $24(54.55 \%)$ & \\
\hline \hline
\end{tabular}

Table 2. Characteristics of patients with RA by metabolic syndrome

\begin{tabular}{l|c|c|c}
\hline \hline & With MetSy & Without MetSy & $\mathrm{p}$ \\
\hline DAS28 & $5.30 \pm 1.12$ & $4.56 \pm 1.14$ & 0.004 \\
\hline CDAI & $23.09 \pm 8.57$ & $17.86 \pm 8.79$ & 0.007 \\
\hline HAQ & $1.2 \pm 0.22$ & $0.83 \pm 0.26$ & 0.001 \\
\hline Duration of disease & $5.59 \pm 6.53$ & $6.24 \pm 6.05$ & 0.397 \\
Female & $31(70.5 \%)$ & $31(83.8 \%)$ & 0.251 \\
Male & $13(29.5 \%)$ & $6(16.2 \%)$ & \\
\hline \hline
\end{tabular}


The prevalence of metabolic syndrome in the study population was $54.3 \%$ (44/81 patients). Patients with metabolic syndrome had statistically significantly higher DAS28 values $(p=0.004)$, CDAI $(p=0.007)$ and higher functional incapacity determined by HAQ questionnaire $(p=0.001)$ (Table 2).

Cardiovascular risk in the HAD group was 12.18 $\pm 8.09 \%$ which was higher compared to MLA group $(10.74 \%)$, but without significance between the compared groups $(\mathrm{p}=0.943)$.

According to disease activity measured by CDAI score, cardiovascular risk in the HAD group was $12.36 \%$ and $11.45 \%$ in the MLA group, but without significance between the compared groups $(p=1.00)$.

Cardiovascular risk was statistically significantly higher in patients with metabolic syndrome $(p<0.001)$. Compared with the parameters of the metabolic syndrome, it was statistically significantly higher in patients with TG $>1.7(\mathrm{p}=0.001), \mathrm{BMI}>25(\mathrm{p}=0.003)$ and glycemic values $>6.1(p=0.011)$.

\section{DISCUSSION}

The results of our study have shown that RA patients high disease activity measured by the DAS28 and CDAI have lower total cholesterol and LDL cholesterol levels compared to the RA patients who have medium or low disease activity. This lipid paradox was also shown by Myasoedova E et al. in 2011, who examined 651 RA patients in their study. The study results suggested that patients with HAD had lower total and LDL cholesterol levels, which on the other hand represented high risk factor for cardiovascular disease in RA patients (14).

Different results were reported on the effect of disease activity on total and LDL cholesterol levels, which may be increased or decreased, while everyone agreed that HDL cholesterol levels were always decreased in active RA (HDL is in the inverted proportion with CRP), which was show by Situnayake RD et al. (15) and Choy E et al. (16). All this led to aterogenic index increase. In 2005, McMahon M et al. emphasized that function of HDL was also disrupted in RA patients because those molecules were unable to protect LDL molecules from oxidation which is an important link in the development of atherosclerosis (17). In addition, HDL cholesterol loses its role in other processes, which results in reduction of its anti-inflammatory and athero-protective effect, as reported by Choy E et al. (16). Mantel-Teeuwisse AK et al. reported that, apart from the disease activity, lipid status was also affected by the mediactions used in RA therapy (18).

Our results showed a high prevalence of metabolic syndrome in RA patients, as well as the association of MetSy with HAD. In 2017, Hallajzadeh J. et al. published a systematic review and meta-analysis which included 70 studies in the period from 2000 to 2016, and showed a high prevalence of MetSy in RA patients (19).

In general autoimmune diseases are significantly associated with accelerated atherosclerosis, increased risk of cardiovascular disease and death, with a partial effect of traditional risk factors for cardiovascular disease. In systemic inflammation and autoimmune reactions, the activation of monocytes and lymphocytes leads to changes in the reactivity of blood vessels' intima and increased deposit of lipid substances. The association between dyslipidemia and atherosclerosis in autoimmune diseases is more complex than in the general population. Particular emphasis is placed on HDL cholesterol fraction. HDL fraction of cholesterol has atheroprotective effects, primarily due to its cholesterol binding, antiinflammatory and antioxidant effects, which does not only depend on the circulating level, but also on the functionality of HDL, which is all impaired in autoimmune diseases (17).

The results of our study have shown a high cardiovascular risk in RA patients, which was higher in the group of patients with the HAD. An increasing number of studies around the world provide convincing evidence of increased CV risk in RA patients compared to the general population.

Solomon et el. reported that women with RA had a two times greater risk of developing myocardial infarction than women without RA (20). A year later, Fischer LM et el. reported an increased risk in men as well (21). Goodsom et el. suggested that the increased risk of developing myocardial infarction was noticed in early polyarthritis if the patients were seropositive, and that they were at the increased risk of premature death due to coronary artery disease. This group of authors especially emphasizes that seropositive women have a twice higher risk, and those younger than 65 have even three times higher risk of cardiovascular mortality than the general population (22). Due to the importance of CVD in RA patients, in 2010 the European Association of Rheumatologists defined the recommendations for reducing the CV risk. They emphasized that seropositivity, HAD and duration of RA over 10 years are the main risk factors for the increased CV risk (23). 
Many authors point out that the true incidence of cardiovascular disease is difficult to assess accurately because they show the tendency to remain asymptomatic in RA patients. These patients do not usually have classical symptoms of angina pectoris, so they often experience unrecognized myocardial infarction or sudden cardiac death. Other authors (Banks MJ et al., Douglas $\mathrm{KM}$ et al.) reported that RA patients who had acute coronary syndrome often had a relapse of an ischemic event, with atypical presentation $(24,25)$. In their research, Van Doornum $\mathrm{S}$ et al. suggested that an increased mortality was observed during the follow-up of these patients after the acute coronary event in the first 30 days compared to the general population (26).

Aubry MC et al. published the results of postmortem studies that analyzed changes in coronary arteries of RA patients compared to the general population (comparable by age, sex and CV anamnesis), suggesting that RA patients reported less atherosclerotic changes and higher level of inflammation and plaque instability than the group without RA (27). Goodson et el. (28) and Gabriel SE et el. reported that the worse outcome of
CVD in these patients was associated with markers of worse RA prognosis, such as seropositivity, the degree of systemic inflammation, number of inflamed joints, and the incidence of extraarticular manifestations. According to their findings, the degree of inflammation is the leading risk factor for this outcome of the disease (29).

\section{CONCLUSION}

Our results suggest statistically significantly more frequent presence of metabolic syndrome in RA patients, which is accompanied with higher disease activity and more severe functional disability.

Total cholesterol and LDL cholesterol levels were lower in patients with high disease activity.

Cardiovascular risk was statistically significantly higher in patients with metabolic syndrome and RA, but without a significant difference regarding the disease activity. 


\section{References}

1. Aletaha D, and Smolen JS. Evaluation and outcomes of patients with rheumatoid arthritis. In: Hochberg MC, Silman AJ, Smolen JS, Weinblatt ME, and Wiesman MH (edds). Rheumatology, $5^{\text {th }}$ edition. Mosby Elsevier, Philadelphia 2011: 941-954.

2. Kaplan MJ. Cardiovascular disease in rheumatoid arthritis. Curr Opin Rheumatol 2006;18:289-9.

3. Arend WP. Physiology of cytokine pathways in rheumatoid arthritis. Arthritis Rheum 2001; 45: 1016.

4. Bartoloni E, Alunno A, Bistoni O. How early is the atherosclerotic risk in rheumatoid arthritis? Autoimmun Rev 2010; 9: 701-7.

5. Aletaha D and Smolen JS. Outcome measurement in rheumatoid arthritis: Disease activity. In Hochberg MC, Silman AJ, Smolen JS, (edds). Rheumatoid Arthritis, 1st ed. Mosby Inc, Philadelphia 2009: 225230.

6. Bruce B, Fries JF. The Stanford Health Assessment Questionnaire: Dimensions and practical applications. Health and quality of life outcomes 2003, 1: 2026.

7. Welsing PMJ, van Gestel AM, Swinkels HL: The relationship between disease activity, joint destruction, and functional capacity over the course of rheumatoid arthritis. Arthritis Rheum 2001; 44: 20092017.

8. Ward MM. Clinical and laboratory measures. In: St. Clair EW, Pisetsky DS, Haynes BF (edds). Rheumatoid arthritis, $1^{\text {st }}$ edition. Lippincott Williams \& Wilkins, Philadelphia 2004: 51-63.

9. Eckel Rh, Grundy SM, Zimmet PZ. The metabolyc syndrome. Lancet. 2005;365: 1415-1428.

10. ACC/AHA guideline on the assessment of cardiovascular risk: a report of the American College of Cardiology/American Heart Association Task Force on Practice Guidelines. Circulation. 2014;129 (suppl 2):S49-S73.

https://doi.org/10.1161/01.cir.0000437741.48606.98

11. Leeb, BF, Andel, I, Leder, S. The patient's perspective and rheumatoid arthritis disease activity indexes [published erratum appears in Rheumatology (Oxford) 2005;44:569]. Rheumatology (Oxford) 2005; 44:360-5.

https://doi.org/10.1093/rheumatology/keh484

12. Falgroneg, Zerkak D, Bauer C: How to define a Minimal Clinically Individual State (MCIS) with pain VAS in daily practice for patients suffering from musculoskeletal disorders. Clin Exp Rheumatol 2005; 23: 235-8.

13. Pincus T, Yazici $Y$, Bergman M. Development of a Multidimensional Health Assessment Questionnaire (MDHAQ) for the infrastructure of standard clinical care. Clin Exp Rheumatol 2005;23 Suppl:S19-28.

14. Myasoedova E, Chandran A, Ithan B. The role of rheumatoid arthritis (RA) flare and cumulative burden of RA severity in the risk of cardiovascular disease. Ann Rheum Dis 2015 Jan 30. [Epub ahead of print].

https://doi.org/10.1136/annrheumdis-2014-206411

15. Situnayake RD, Kitas GD. Dyslipidaemia and rheumatoid arthritis. Ann RheumDis 1997; 56: 341-2. https://doi.org/10.1136/ard.56.6.341

16. Choy E, Ganeshalingam K, Semb AG. Cardiovascular risk in rheumatoid arthritis: recent advances in the understanding of the pivotal role of inflammation, risk predictors and the impact of treatment. Rheumatology (Oxford) 2014; 53(12): 2143-54. https://doi.org/10.1093/rheumatology/keu224

17. McMahon M, Grossman J, Fitzgerald J, et al. Proinflammatory high-density lipoprotein as a biomarker for atherosclerosis in patients with systemic lupus erythematosus and rheumatoid arthritis. Arthritis Rheum 2006; 54(8): 2541-9. 
18. Mantel-Teeuwisse AK, Kloosterman JME, et al Drug-induced lipid changes: a review of the unintended effects of some commonly used drugs on serum lipid levels. Drug Safety 2001; 24: 443-56. https://doi.org/10.2165/00002018-200124060-00003

19. Metabolic syndrome and its components among rheumatoid arthritis patients: A comprehensive updated systematic review and meta-analysis. PLoS One. 2017;12(3):e0170361.

https://doi.org/10.1371/journal.pone.0170361

20. Solomon DH, Karlson EW, Rimm EB, et al. Cardiovascular morbidity and mortality in women diagnosed with rheumatoid arthritis. Circulation 2003; 107: 1303-7.

https://doi.org/10.1161/01.CIR.0000054612.26458.B2

21. Fischer LM, Schlienger RG, Matter C, et al. Effect of rheumatoid arthritis or systemic lupus erythematosus on the risk of first-time acute myocardial infarction. Am J Cardiol 2004; 93: 198-200. https://doi.org/10.1016/j.amjcard.2003.09.037

22. Goodson N. Coronary artery disease and rheumatoid arthritis. Curr Opin Rheumatol 2002; 14: 115-20. https://doi.org/10.1097/00002281-200203000-00007

23. Peters MJ, Symmons DP, McCarey D, et al. EULAR evidence-based recommendations for cardiovascular risk management in patients with rheumatoid arthritis and other forms of inflammatory arthritis. Ann Rheum Dis 2010; 69: 325-31. https://doi.org/10.1136/ard.2009.113696
24. Banks MJ, Pace A, Kitas GD. Acute coronary syndromes present atypically and recur more frequently in rheumatoid arthritis than matched controls [abstract], Arthritis Rheum 2001; 44(Suppl.): S53

25. Douglas KM, Pace AV, Treharne GJ, et al. Excess recurrent cardiac events in rheumatoid arthritis patients with acute coronary syndrome. Ann Rheum Dis 2006; 65: 348-53.

https://doi.org/10.1136/ard.2005.037978

26. Van Doornum S, King B, Brand C. Mortality rates following a first acute cardiovascular event: a comparison between rheumatoid arthritis patients and the general population. Arthritis Rheum 2005; 52: S702.

27. Aubry MC, Maradit-Kremers H, Reinalda MS. Differences in atherosclerotic coronary heart disease between subjects with and without rheumatoid arthritis. J Rheumatol 2007; 34: 937-42.

28. Goodson NJ, Symmons DP, Scott DG, et al. Baseline levels of C-reactive protein and prediction of death from cardiovascular disease in patients with inflammatory polyarthritis: a ten-year follow up study of a primary care-based inception cohort. Arthritis Rheum 2005; 52: 2293-9.

https://doi.org/10.1002/art.21204

29. Gabriel SE. Heart disease and rheumatoid arthritis: understanding the risks. Ann Rheum Dis 2010; 69 (Suppl 1): i61-4. https://doi.org/10.1136/ard.2009.119404 


\title{
Uticaj aktivnosti reumatidnog artritisa na metabolički sindrom i procena kardiovaskularnog rizika
}

\author{
Ivana Aleksić1, Sonja Stojanović1,2, Ivan Tasić1,2, Bojana Stamenković1,2 \\ Institut za lečenje i rehabilitaciju "Niška Banja“, Niš, Srbija \\ ${ }^{2}$ Univerzitet u Nišu, Medicinski fakultet, Niš, Srbija
}

\section{SAŽETAK}

Pacijenti sa reumatoidnim artritisom imaju 1,5 puta veću stopu mortaliteta od kardiovaskularnih bolesti u odnosu na opštu populaciju, a životni vek ovih bolesnika je od 5 do 10 godina kraći u odnosu na opštu populaciju. Jedno od objašnjenja je da su kod RA svi stadijumi aterogenog procesa ubrzani. Sistemska inflamacija, koja leži u osnovi RA, nezavisan je faktor rizika za kardiovaskularne bolesti.

Cilj rada bio je ispitati lipidni status i učestalost metaboličkog sindroma kod bolesnika sa reumatoidnim artritisom, kao i njihovu povezanost sa aktivnošću bolesti i funkcionalnim oštećenjem. Takođe, cilj rada bio je proceniti kardiovaskularni rizik kod bolesnika sa reumatoidnim artritisom $\mathbf{u}$ odnosu na aktivnost bolesti, kao $i$ povezanost sa pojedinačnim komponentama metaboličkog sindroma.

Istraživanje je obuhvatilo 81 bolesnika sa RA (19 muškaraca i 62 žene), prosečne starosti 59,7 godina $\pm 11,2$ godine i prosečne dužine trajanja bolesti 5,89 godina $\pm 6,25$ godina. Kod svih bolesnika sa RA urađeni su klinički pregled i laboratorija (SE, KS, CRP, RF, gly, Hol, LDL, HDL, Tg) i mereni su krvni pritisak, telesna težina i visina (izračunat je indeks telesne mase). Prisustvo metaboličkog sindroma određivano je prema definiciji Internacionalne federacije za dijabetes. Za izračunavanje kardiovaskularnog rizika korišćen je ACC/AHA ASCVD kalkulator rizika. Aktivnost bolesti prikazana je preko DAS28SE i CDAI. Funkcionalna sposobnost bolesnika procenjena je na osnovu HAQ upitnika za procenu zdravstvenog stanja.

Prema stepenu aktivnosti bolesti iskazanom preko DAS28SE svi bolesnici bili su podeljeni u 2 grupe. Prvu grupu (visoka aktivnost bolesti) DAS28SE > 5,1 činilo je 37 bolesnika (45,7\%), a drugu grupu (umerena, niska aktivnost bolesti i remisija) DAS28SE $\leq 5,1$ činilo je 44 bolesnika (54,3\%). Prosečna vrednost ukupnog holesterola kod svih ispitanika iznosila je 5,44 $\pm 1,03$ i to u grupi DAS28 $>5,15,22 \pm 1,03$, a u grupi DAS28 $\leq 5,15,68 \pm 1,03$. Nađena je statistički značajna razlika među poređenim grupama $(p=0,029)$. U grupi ispitanika sa DAS28 $>5,1$ vrednosti LDL holesterola bile su niže u odnosu na grupu ispitanika sa DAS28SE $\leq 5,1(2,84 \pm 0,80$ prema $3,34 \pm$ $0,80)$. Pronađena je statistički značajna razlika među poređenim grupama $(p=0,033)$. U grupi bolesnika sa DAS28SE > 5,1 metabolički sindrom imalo je 24 od 37 bolesnika $(64,86 \%)$ što je bilo satistički značajno više u odnosu na grupu ispitanika sa DAS28SE $\leq 5,1$ u kojoj je 20 od 44 bolesnika imalo metabolički sindrom (45,45\%; p $=0,042$ ). Prevalencija metaboličkog sindroma $u$ ispitivanoj populaciji iznosila je 54,3\% (44 bolesnika od 81 bolesnika). Pacijenti sa metaboličkim sindromom imali su statistički značajno veće vrednosti DAS28 $(p=0,004)$ i CDAI ( $p=0,007)$, kao i statistički značajno veću funkcijsku nesposobnost određenu HAQ upitnikom $(p=0,001)$. Kardiovaskularni rizik u grupi ispitanika sa DAS28SE $>5,1$ iznosio je 12,18\% $\pm 8,09 \%$ i bio je veći u odnosu na 
grupu sa DAS28SE $\leq 5,1$ gde je bio $10,74 \%$, bez statistički značajne razlike među poređenim grupama ( $p=0,943)$. Kardiovaskularni rizik bio je statistički značajno veći kod pacijenata sa metaboličkim sindromom $(\mathrm{p}<0,001)$.

Naši rezultati pokazali su da je metabolički sindrom statistički značajno više zastupljen kod bolesnika sa reumatoidnim artritisom koji su imali visoku aktivnost bolesti i težu funkcijsku nesposobnost. Vrednosti ukupnog holesterola i LDL holesterola bile su niže kod bolesnika sa visokom aktivnošću bolesti. Kardiovaskularni rizik bio je statistički značajno veći kod pacijenata sa metaboličkim sindromom i reumatoidnim artritisom, ali bez značajne razlike u odnosu na aktivnost bolesti.

Ključne reči: reumatoidni artritis, lipidni status, metabolički sindrom, kardiovaskularni rizik 